\title{
Conflict over scope of research splits Human Frontier programme
}

Tokyo, Washington \& London. The Japanese scientists who helped create the Human Frontier Science Program (HFSP) are for the first time publicly feuding with some of the project's international administrators over the scope of the $\$ 34$ million research effort to understand the functions of the brain and living organisms. The Japanese fear that a proposed focus of the programme to only a few established fields of biology might limit the opportunities for international and interdisciplinary collaboration and significantly reduce the pool of applicants.

Their unhappiness reflects a long-running but previously private dispute between the Japanese and the outgoing secretary general of the programme, Sir James Gowans, over the direction of the programme. It surfaced last month after a letter was sent to the programme's scientific advisers about a recent article in Nature (357, $356 ; 1992$ ) by Akiyoshi Wada, director of the Sagami Chemical Research Centre and one of the architects of the programme. The letter, from J. Edward Rall, chairman of the HFSP

Council of Scientists and a scientist at the US National Institutes of Health, said that Wada's opinions had not been discussed by the council and should not be taken as HFSP policy.

Wada and other Japanese scientists consider Rall's letter to be an unjustified and unnecessary rebuke of Wada and an oblique criticism of his philosophy, which is shared by a majority of the council. Rall says that Wada, as a former council member, should not be speaking for the programme and that the letter simply makes clear that the philosophy of the programme has not changed. He says that he and Gowans decided to send out the letter after several researchers called the programme's headquarters in Strasbourg to ask whether they should tailor their proposals to meet Wada's vision. The council will discuss the subject at its meeting in November.

Much of the present acrimony can be traced to a council meeting in March 1991 at which one or two members suggested lowering the rejection rate for applicants by confining the programme that deals with molecular-level approaches to understanding living organisms to such traditional fields as cellular and developmental biology. $\mathrm{Al}-$ though several members of the council objected during a brief discussion, according to Wada, a report of the meeting drafted by Gowans and presented by Rall to the HFSP board of trustees in April implied that the council endorsed the change. Wada wrote to Rall to protest, and at the next council meeting in May the idea was voted down.

time to change things later on, if changes are needed".

For Wada and other Japanese officials, however, those changes appear imminent as new countries begin to contribute money to the programme. The Japanese have so far provided nearly all the funding, although the United States has promised to spend $\$ 5.5$ million during the fiscal year that starts in October.

Joseph Varner, a biologist at Washington University in St Louis, Missouri, who retired from the council this past spring, agrees that money will play an important role in shaping the programme's direction. But he says that "Wada's remarks are inappropriate because, right now, there just isn't enough money to do what he wants. If there was $\$ 300$ million instead of $\$ 30$ million, then you could do a lot more."

Wada says he is just trying to reaffirm the principles established by the international feasibility committee, which he chaired, as well as opening up the debate to a wider audience. "I am not against narrowing the programme as such", he

Gowans is not a member of the council but is said to support the notion of a narrower focus. Japanese staff in Strasbourg and Japanese members of the Council of Scientists have repeatedly told him that such an approach violates the principle of 'interdisciplinarity' enunciated in a study that helped to launch the programme in 1989 and they have explained to him that the principal means interactive research between disciplines such as physics, chemistry and mathematics as well as biology. But Gowans is said to believe that the principle refers to interdisciplinary research between fields of biology, such as cellular and developmental biology.

Gowans has declined to discuss the matter in detail unless Nature reveals its source of Rall's letter but he says there is no disagreement within the council on the scope of the programme. And Rall believes that, in retrospect, last year's decision not to narrow the programme was correct. "There is no point in trying to change things so early in the programme", he says. "There is plenty of says, "but the matter should be debated with the same time and care as went into the feasibility study."

The uproar could affect the selection of the next secretary general, who will take office next spring. Any of the HFSP members (United States, Japan, United Kingdom, France, Germany, Italy, Canada, Switzerland and the European Communities) may nominate candidates, who will be screened by the council and voted on by the programme's board of trustees. Both the council and the board have two representatives from each member country.

Several non-Japanese members of the two bodies believe that Japan must begin to relinquish some control if it wants HFSP to be a truly international programme. But the Japanese Ministry of Finance is likely to insist on maintaining a significant number of Japanese staff in the secretariat in Strasbourg as long as Japan provides the bulk of the funding.

David Swinbanks, Jeffrey Mervis \& Alison Abbott 